\title{
STRATEGI PENINGKATAN PERTUMBUHAN DANA ZAKAT PADA BADAN AMIL ZAKAT NASIONAL KABUPATEN BENGKALIS
}

\author{
Sulistyandari \\ Fakultas Ekonomi dan Bisnis, Universitas Muhammadiyah Riau \\ Email : sulistyandari@umri.ac.id
}

\begin{abstract}
ABSTRAK
Penelitian ini bertujuan untuk mengetahui strategi dalam meningkatkan pertumbuhan dana zakat di Kabupaten Bengkalis. Penelitian dilakukan dengan pendekatan kualitatif dengan metode deskriptif yang datanya diperoleh melalui wawancara, observasi, dokumentasi dan literature review. Hasil penelitian menunjukkan bahwa strategi yang dipakai oleh Badan Amil Zakat Nasional Kabupaten Bengkalis untuk meningkatkan pengumpulan dana zakat adalah dengan peningkatan kerjasama dengan berbagai instansi termasuk instansi pemerintah; menambah frekuensi sosialisasi melalui pelaksanaan seminar dan workshop zakat; meningkatkan kompetensi SDM amil, UPZ dan relawan serta mengembangkan sistem ICT dalam pengelolaan zakat. Sedangkan yang menjadi hambatan adalah kurangnya pemahaman masyarakat tentang zakat dan kurangnya kepercayaan masyarakat kepada Badan Amil Zakat Nasional Kabupaten Bengkalis. Adapun solusi yang diterapkan oleh BAZNAS Kabupaten Bengkalis untuk mengatasi hambatan diantaranya adalah transparansi pengelolaan; modernisasi pengelolaan dan publikasi.
\end{abstract}

Kata kunci : Strategi, Solusi, BAZNAS, Zakat.

\begin{abstract}
This study aims to determine strategies to increase the growth of zakat funds in Bengkalis Regency. The research was conducted with a qualitative approach with descriptive methods, the data were obtained through interviews, observation, documentation and literature review. The results showed that the strategy used by Bengkalis National Zakat Agency to increase the collection of zakat funds was include increasing cooperation with various agencies including government agencies; increasing the frequency of socialization through the implementation of zakat seminars and workshops; increasing the competence of amil human resources, UPZ and volunteers and developing an ICT system in managing zakat. Whereas the limitation is the lack of public understanding of zakat and the lack of public trust in the Bengkalis National Zakat Agency. The solutions applied by the Bengkalis BAZNAS to overcome these limitations include management transparency; modernization of management and publication.
\end{abstract}

Keywords : Strategy, Solutions, BAZNAS, Zakat. 


\section{PENDAHULUAN}

Zakat adalah harta yang wajib dikeluarkan oleh seorang muslim atau badan usaha untuk diberikan kepada yang berhak menerimanya sesuai dengan syariat Islam. Zakat dalam pelaksanaannya harus ditetapkan dan diatur oleh agama dan negara, baik dari segi jenis harta yang dizakatkan, para wajib zakat (muzakki), maupun para penerima zakat (mustahik), sampai pada pengelolaannya oleh pihak ketiga, dalam hal ini pemerintah atau lembaga yang ditunjuk oleh pemerintah untuk mengelola zakat demi kemaslahatan ummat.

Kedudukan zakat bisa menjadi sangat penting bagi perekonomian umat apabila zakat bisa dikelola secara optimal. Bila potensi zakat bisa dimaksimalkan, maka sangat mungkin untuk dimanfaatkan dalam menunjang kegiatan ekonomi dan proses pengentasan kemiskinan, khususnya bagi masyarakat muslim. Dengan adanya zakat bisa meminimalisir potensi kesenjangan sosial dan meningkatkan kesejahteraan.

Pengumpulan zakat yang dilakukan oleh Badan Amil Zakat Nasional dengan cara menerima atau mengambil dari muzakki atas dasar pemberitahuan dari muzakki. Penghimpunan dana zakat boleh dikatakan selalu menjadi tema besar organisasi amil zakat (Khasanah, 2010). Pelaksanaan pemungutan zakat secara semestinya, secara ekonomik dapat menghapus tingkat perbedaan kekayaan yang mencolok, serta sebaliknya dapat menciptakan redistribusi yang merata (Mannan, 1997).

Salah satu indikator kemajuan zakat di Indonesia yaitu terjadi peningkatan penghimpunan zakat, termasuk infaq dan sedekah, yang cukup tinggi dari tahun ke tahun. Namun demikian, di balik pesatnya kemajuan dunia perzakatan di Indonesia, masih terdapat banyak persoalan yang perlu diselesaikan. Kesenjangan potensi dan penghimpunan zakat, masih lemahnya perhatian masyarakat terhadap zakat, masalah kredibilitas lembaga, masalah SDM amil, masalah regulasi masyarakat, dan masalah efektivitas serta efesiensi program pemberdayaan zakat yaitu sederet persoalan yang perlu dicarikan solusinya.

Berikut adalah data pengumpulan dana zakat nasional tahun 2015-2019 :

Tabel 1. Pengumpulan Dana Zakat Nasional Tahun 2015 - 2019

\begin{tabular}{cccccc}
\hline \multirow{2}{*}{ Deskripsi } & \multicolumn{5}{c}{ Dana Zakat ( milliar rupiah ) } \\
\cline { 2 - 6 } & $\mathbf{2 0 1 5}$ & $\mathbf{2 0 1 6}$ & $\mathbf{2 0 1 7}$ & $\mathbf{2 0 1 8}$ & $\mathbf{2 0 1 9}$ \\
\hline Zakat Maal Perorangan & 1.983 .4 & 2.843 .7 & 2.785 .2 & 3.302 .2 & 3.951 .1 \\
\hline Zakat Maal Badan & 157.8 & 620.5 & 307.0 & 492.4 & 306.7 \\
\hline Zakat Fitrah & 168.1 & 274.0 & 1.101 .9 & 1.112 .6 & 1.406 .1 \\
\hline TOTAL & $\mathbf{2 . 3 0 9 . 3}$ & $\mathbf{3 . 7 3 8 . 2}$ & $\mathbf{3 . 9 1 7 . 8 4 . 1 9 4 . 1}$ & $\mathbf{4 . 9 0 7 . 2}$ & $\mathbf{5 . 6 6 3 . 9}$ \\
\hline \multicolumn{5}{c}{ Sumber $:$ Statistik Zakat Nasional (2020) }
\end{tabular}

Berdasarkan data tabel 1, potensi zakat yang dimiliki dengan pengumpulan dana zakat di Indonesia dari realisasi penghimpunannya. Ini tahun 2015 sampai dengan tahun 2019 menunjukkan bahwa perhatian dan menunjukkan peningkatan setiap pemahaman masyarakat Indonesia tahunnya. Tetapi jika dibandingkan terhadap zakat masih harus ditingkatkan. dengan penduduk Indonesia yang Dalam Hafiduddhin (2002), disebutkan mayoritas muslim (lebih dari 87\%), bahwa salah satu langkah yang dapat dengan jumlah penduduk sebesar 268 juta dilakukan untuk menggali potensi zakat jiwa pada tahun 2019, maka terdapat yaitu dengan cara sosialisasi dan edukasi kesenjangan yang cukup besar antara kepada masyarakat terkait dengan hukum 
dan hikmah zakatnya, serta objek zakat sekaligus tata cara perhitungannya.

Penelitian Fajri (2020) yang menguji pengaruh implementasi strategi terhadap pertumbuhan zakat di kota Padang, menyatakan bahwa BAZNAS kota Padang melakukan strategi pemetaan; membangun komunikasi mustahiqmuzakki dan membuka gray/stand di pusat perbelanjaan dan gedung pemerintahan. Sedangkan penelitian Kadir dan Nafis (2017) yang meneliti strategi pengumpulan dana zakat di provinsi DKI Jakarta menyimpulkan bahwa tiga (3) jurus strategi untuk peningkatan penghimpunan zakat adalah kerjasama program pengembangan di masyarakat dengan lembaga/organisasi amal lainnya; meningkatkan kapasitas amil dan melakukan kerjasama penelitian dengan lembaga penelitian.

Beberapa strategi untuk menunjang pengelolaan zakat yang lebih baik sangat dibutuhkan. Sebab, dengan strategi itu, maka pengelolaan zakat yang amanah, professional, transparan, dan akuntabel serta memperhatikan kepatuhan syariah dapat terwujud.

Kabupaten Bengkalis merupakan salah satu kabupaten di Provinsi Riau dengan wilayah terdiri dari daratan dan kepulauan dengan luas daerah 8.403,28 $\mathrm{km}^{2}$. Kabupaten Bengkalis merupakan Kabupaten terluar di Indonesia yang berbatasan langsung dengan Malaysia dan Selat Melaka sebagai pembatasnya. Kabupaten Bengkalis terdiri dari 11 Kecamatan, 19 Kelurahan dan 136 desa dengan jumlah penduduk pada tahun 2019 sebesar 553.938 jiwa. Mayoritas penduduk di Kabupaten Bengkalis beragama Islam sebanyak $79,16 \%$ yang diyakini mempunyai potensi yang besar dalam pengumpulan dana zakat.

\section{TINJAUAN PUSTAKA}

\section{Pengertian Zakat}

Ditinjau dari segi bahasa, kata zakat mempunyai arti, yaitu al-barakatu 'keberkahan', al-namaa 'pertumbuhan dan perkembangan' dan ath-thaharatu 'kesucian' dan ash-shalahu 'keberesan' (Hafidhuddin, 2002). Sedangkan secara istilah, meskipun para ulama mengemukakannya dengan redaksi yang agak berbeda antara satu sama lain, akan tetapi pada prinsipnya sama yaitu bahwa zakat adalah bagian dari harta dengan persyaratan tertentu, yang Allah SWT mewajibkan kepada pemiliknya untuk diserahkan kepada yang berhak menerimanya, dengan persyaratan tertentu pula.

Harta yang wajib dizakati adalah harta yang berkembang (Hasan, 2006). Syarat harta yang dikeluarkan zakatnya yaitu sampai nisab dan telah dimiliki satu tahun (haul). Di dalam Al-Qur'an, harta yang wajib dikeluarkan zakat yaitu emas dan perak, tanaman hasil bumi dan buahbuahan, binatang ternak, harta dagang, barang-barang tambang dan kekayaan yang bersifat umum.

\section{Undang-undang Tentang Pengelolaan Zakat}

\section{Undang-Undang No. 38 Tahun 1999}

Undang-Undang No. 38 Tahun 1999 ini lebih menekankan pada aspek pengelolaan zakat yakni kegiatan perencanaan, pengorganisasian, pelaksanaan, dan pengawasan terhadap pengumpulan dan pendistribusian serta pendayagunaan dana zakat. Didalam Undang-Undang tersebut kita tidak akan menemukan ketentuan nisab, kadar, dan waktu pengeluaran zakat. Hal yang terbanyak diungkapkan di dalam UndangUndang No. 38 tahun 1999 ini adalah tentang prinsip-prinsip dan teknis pengelolaan zakat. 


\section{Undang-Undang No. 23 Tahun 2011}

Pengelolaan zakat berdasarkan Undang-Undang No. 38 Tahun 1999 dinilai sudah tidak sesuai lagi dengan perkembangan kebutuhan hukum dalam masyarakat sehingga perlu diganti. Pengelolaan zakat yang diatur dalam Undang-Undang ini meliputi kegiatan perencanaan, pengumpulan, pendistribusian dan pendayagunaan.

Dalam upaya mencapai tujuan pengelolaan zakat maka dibentuk Badan Amil Zakat Nasional (BAZNAS) yang berkedudukan di ibu kota negara, BAZNAS provinsi, BAZNAS kabupaten/kota. BAZNAS merupakan lembaga pemerintah nonstruktural yang bersifat mandiri dan bertanggung jawab kepada Presiden melalui Menteri. BAZNAS merupakan lembaga yang berwenang melakukan tugas pengelolaan zakat secara nasional. Sedangkan untuk pendistribusian dan pendayagunaan zakat, masyarakat dapat membentuk Lembaga Amil Zakat (LAZ). Pembentukan LAZ wajib mendapat izin Menteri atau pejabat yang ditunjuk oleh Menteri. LAZ wajib melaporkan secara berkala kepada BAZNAS atas pelaksanaan pengumpulan, pendistribusian dan pendayagunaan zakat yang telah diaudit syariah dan keuangan.

Selain menerima zakat, BAZNAS atau LAZ juga dapat menerima infak, sedekah, dan dana sosial keagamaan lainnya. Pendistribusian dan pendayagunaan infak, sedekah, dan dana sosial keagamaan lainnya dilakukan sesuai dengan syariat Islam dan dilakukan sesuai dengan peruntukan yang diikrarkan oleh pemberi dan harus dilakukan pencatatan dalam pembukuan tersendiri. Untuk melaksanakan tugasnya, BAZNAS dibiayai dengan Anggaran Pendapatan dan Belanja Negara dan Hak amil. Sedangkan BAZNAS provinsi dan BAZNAS kabupaten/kota dibiayai dengan Anggaran Pendapatan dan Belanja Daerah dan Hak amil, serta juga dapat dibiayai dengan Anggaran Pendapatan dan Belanja Negara.

\section{Peraturan Daerah Kabupaten Bengkalis No. 3 Tahun 2018}

1. Dalam rangka pengumpulan zakat, muzakki melakukan penghitungan sendiri atas kewajiban zakatnya.

2. Dalam hal tidak dapat menghitung sendiri kewajiban zakatnya, muzakki dapat meminta bantuan BAZNAS Kabupaten dan LAZ.

3. BAZNAS Kabupaten dan LAZ dapat bekerjasama dengan bank atau lembaga keuangan lainnya di wilayah Kabupaten Bengkalis dalam mengumpulkan dana zakat dan harta muzakki.

4. Untuk terlaksananya kerjasama sebagaimana maksud pada ayat (3) perlu dilakukan kesepakatan bersama dan disosialisasikan kepada masyarakat secara luas, melalui media cetak, media elektronik, atau pembuatan leaflet.

5. Dalam rangka mengoptimalkan pengumpulan zakat BAZNAS Kabupaten dan LAZ dapat menyebarkan programnya melalui iklan dengan mencantumkan nomor rekening pembayaran dana zakat dan lain-lain.

6. Muzakki dapat membayar zakatnya melalui nomor rekening BAZNAS Kabupaten dan LAZ.

\section{Pemberdayaan Zakat untuk Mustahik}

Zakat menjadi salah satu solusi alternatif dalam membangun ekonomi umat, sekaligus menciptakan iklim solidaritas sesama manusia. Dalam kaitannya dengan cita-cita membangun ekonomi umat, dapat dilihat dalam dua tingkatan permasalahan. Pertama pada tingkat pelaksanaan zakat, dan kedua pada 
tingkat pendayagunaan serta pendistribusiannya (Mufraini, 2006).

Pada tingkat pelaksanaan, penyelesaian masalah akan banyak melibatkan alim ulama dan para fuqaha. Umpamanya dalam hal ketentuan hukum mengenai zakat bagi kalangan profesional yang tidak bertani atau berdagang tetapi memperoleh kekayaan yang lebih besar. Pada tingkat pendistribusian dan pendayagunaan, pelaksanaan zakat juga masih memiliki masalah. Ketika potensi kekayaan umat masih sangat terbatas, mungkin tidak ada masalah dalam mendistribusikan dan mendayagunakan zakat itu. Ketika zakat sudah mencapai jumlah angka yang besar, bermunculanlah permasalahan baru. Dengan besarnya potensi umat ini tentu perlu adanya peningkatan pengelolaan secara profesional dan proporsional serta lebih berdayaguna bagi kepentingan umat.

Persoalan manajemen zakat diawali oleh adanya kesenjangan antara potensi dan realita. Pada kondisi ini kesenjangan manajemen dibagi menjadi empat faktor pokok yaitu keberadaan sumber dana, pengorganisasian, pelaporan dan pemanfaatan sasaran. Untuk membahas semua persoalan kesenjangan diatas dibutuhkan pemahaman tentang kerangka sistem terpadu yaitu kerangka sistem yang meliputi orientasi organisasi sebagai berikut : orientasi sumber (input), orientasi proses, dan orientasi tujuan (output) (Ali, 2006).

\section{Pengertian Strategi}

$\begin{array}{cccc}\text { Strategi berasal dari bahasa } & \text { bunani kuno yang berarti "seni }\end{array}$ berperang". Suatu strategi mempunyai dasar-dasar atau skema untuk mencapai sasaran yang dituju. Jadi, pada dasarnya strategi merupakan alat untuk mencapai tujuan. Dalam konteks bisnis, strategi menggambarkan arah bisnis yang mengikuti lingkungan yang dipilih dan merupakan pedoman untuk mengalokasikan sumber daya dan usaha suatu organisasi.

Menurut Tjiptono
pernyataan strategi secara eksplisit
merupakan kunci keberhasilan dalam
menghadapi perubahan lingkungan bisnis.
Strategi memberikan kesatuan arah bagi
semua anggota organisasi. Bila konsep
konsentrasi tidak jelas, maka keputusan
yang diambil akan bersifat subjektif atau
berdasarkan intuisi belaka dan
mengabaikan keputusan yang lain.

\section{Tingkatan Strategi}

1. Strategi Korporat. Adalah strategi yang disusun dalam suatu bisnis sehingga perusahaan akan bersaing dengan cara mengubah distinctive competence menjadi competitive advantage. Pada tingkat korporat ini, strategi korporat berusaha menjawab pertanyaan : kegiatan bisnis apakah yang diunggulkan untuk dapat bersaing ? bagaimana masing-masing kegiatan bisnis tersebut dapat dilakukan secara terintegrasi ?

2. Strategi Bisnis. Pengertian strategi di tingkat bisnis adalah sekumpulan komitmen dan tindakan perusahaan yang terpadu dan terkoordinasi yang digunakan untuk mendapatkan keunggulan bersaing dengan mengeksploitasi kompetensi inti dalam pasar produk yang spesifik. Strategi pada tingkatan ini harus konsisten dengan strategi bisnis keseluruhan yang dikhususkan untuk line of business tersebut.

3. Strategi Fungsional. Strategi fungsional adalah aktifitas jangka pendek dalam perusahaan yang harus dikembangkan oleh setiap bidang fungsi perusahaan untuk mengimplementasikan strategi korporat dan strategi bisnis pada masing-masing departemen atau bagian. Strategi fungsional harus dapat menerjemahkan pemikiran pada 
strategi korporat dan strategi bisnis menjadi suatu tindakan guna mencapai tujuan tahunan. Dalam perumusannya, strategi fungsional haruslah meliputi seluruh fungsi yang ada dalam perusahaan dan hal ini dapat berbedabeda antar perusahaan bergantung pada jenis industri dan skala bisnis yang dimiliki. Fungsi-fungsi dasar yang umumnya terdapat dalam perusahaan antara lain fungsi produksi operasi, fungsi pemasaran, fungsi keuangan dan fungsi pengelolaan sumber daya manusia.

\section{METODE PENELITIAN}

\section{Desain Penelitian}

Penelitian ini dirancang dengan menggunakan jenis penelitian kualitatif yang dilakukan untuk mengidentifikasi terhadap permasalahan dalam pengumpulan zakat di Kabupaten Bengkalis. Dari permasalahan tersebut akan memunculkan solusi dan seterusnya akan ditetapkan strategi yang akan digunakan dalam menerapkan pengumpulan zakat di Kabupaten Bengkalis. Menurut (Moleong, 2017), penelitian kualitatif berguna untuk memahami fenomena tentang apa yang dialami oleh subyek penelitian: misalnya prilaku, persepsi, motivasi, dan tindakan lainnya, secara holistic dan secara deskriptif dalam bentuk kata-kata dan bahasa dalam suatu konteks khusus yang alamiah dengan memakai metode ilmiah.

\section{Metode Pengumpulan Data}

Data penelitian ini dikumpulkan dalam beberapa cara, yaitu :

1. Wawancara (interview). Merupakan teknik pengumpulan data dengan cara mengajukan tanya jawab secara langsung di Badan Amil Zakat Nasional Kabupaten Bengkalis. Dan dapat pula dikatakan bahwa wawancara merupakan percakapan tatap muka antara pewawancara dengan sumber informasi, dimana pewawancara bertanya langsung suatu objek yang diteliti yang telah dirancang sebelumnya. (Yusuf, 2014)

2. Dokumentasi, merupakan teknik pengumpulan data yang dilakukan dengan cara mengumpulkan data dari instansi dalam bentuk yang jadi tanpa perlu diubah.

3. Observasi, adalah pengamatan dengan melakukan pencatatan atau pengkodean perilaku individu atau suasana, kondisi, dan sebagainya.

4. Literature review, dengan mempelajari penelitian-penelitian terdahulu yang relevan dengan penelitian ini.

\section{Metode Analisis Data}

Analisis data yang digunakan dalam kajian ini yaitu menggunakan pendekatan kualitatif dengan metode deskriptif yaitu menggambarkan sifat sesuatu yang tengah berlangsung pada saat riset dilakukan dan memeriksa sebabsebab dari suatu gejala tertentu (Yusuf, 2014). Data diperoleh melalui observasi, wawancara, dokumentasi dan literature review. Dalam penelitian ini yang dideskripsikan adalah strategi pertumbuhan dana zakat pada Badan Amil Zakat Nasional Kabupaten Bengkalis. Dalam menganalisis data penelitian ini menggunakan cara pengumpulan data dan kemudian dibandingkan dengan teori yang ada (Trianto, 2015). Peneliti hanya terfokus pada strategi pertumbuhan dana zakat dari tahun 2017-2018. Sehingga dapat tergambar secara utuh bagaimana kesimpulannya.

\section{HASIL DAN PEMBAHASAN}

Berdasarkan hasil wawancara dengan Amil Bagian Pengumpulan BAZNAS Kabupaten Bengkalis tentang strategi pengumpulan zakat diperoleh data bahwa strategi yang digunakan BAZNAS Kabupaten Bengkalis dalam meningkatkan pertumbuhan dana zakat diantaranya adalah : 
1. Memaksimalkan penggunaan kekuatan internal yang dimiliki BAZNAS Kabupaten Bengkalis untuk memanfaatkan peluang yang ada secara maksimal. Strategi yang digunakan:

a. Perluasan penggalian dana-dana zakat yang potensial dan mengumpulkan dana dengan memanfaatkan kekuatan pemerintah Kabupaten Bengkalis.

b. Memaksimalkan pemungutan zakat secara online.

c. Memperluas jaringan dan sosialisasi.

d. Melakukan kerjasama pengumpulan zakat dengan unit kerja Pemda.

2. Menggunakan kekuatan internal untuk menghadapi dan meminimalisir ancaman-ancaman eksternal. Alternatif strategi yang dilakukan antara lain :

a. Sosialisasi dan audiensi yang intens kepada Pemda Bengkalis agar urusan zakat mendapat perhatian lebih baik oleh pihak Pemda Bengkalis.

b. Meningkatkan sosialiasi dan edukasi tentang zakat di masyarakat.

c. Mengemas program pendayagunaan dengan lebih baik sehingga dapat digunakan untuk sosialisasi dan meningkatkan kepercayaan masyarakat.

3. Mengatasi kelemahan internal dengan memanfaatkan peluang eksternal yang ada. Alternatif strategi yang dilakukan antara lain:

a. Merancang program dan target jangka panjang dan jangka pendek yang terintegrasi.

b. Melakukan sinergi program pemberdayaan masyarakat dengan UPZ di Bengkalis.

c. Meningkatkan kapasitasi SDM amil dengan melakukan pendidikan dan pelatihan. d. Melakukan kerjasama dengan lembaga pendidikan.

e. Memanfaatkan kemajuan teknologi untuk meningkatkan sosialisasi dan edukasi masyarakat tentang zakat.

4. Mengatasi kelemahan internal sekaligus mengatasi ancaman eksternal. Alternatif srategi yang dilakukan :

a. Mengambil kebijakan untuk merekrut SDM amil dan relawan.

b. Melakukan sharing knowledge dengan LAZ dan Unit Pengumpul Zakat.

Selain itu, beberapa hal yang dilakukan BAZNAS Kabupaten Bengkalis dalam meningkatkan pertumbuhan dana zakat antara lain :

1. Penguatan fondasi BAZNAS

Kabupaten Bengkalis. Penggunaan fondasi mencakup aspek legalitas lembaga dan kepemimpinannya, kesesuaian dengan syariah dalam pengelolaan zakat, infak, dan sedekah, akuntabilitas pengelolaan zakat, anggota amilin yang kredible, amanah dan kompeten, pengumpulan serta penyaluran zakat yang optimal.

2. Pengelolaan zakat yang terintegrasi secara nasional. Integrasi pengelolaan zakat yang dilakukan dengan pemanfaatan teknologi informasi yang dapat diakses dengan mudah, cepat dan efesien.

3. Teknologi informasi sebagai tulang punggung pengelolaan zakat nasional. Pembangunan sistem perzakatan nasional harus memanfaatkan perkembangan teknologi informasi sebagai instrument percepatan dalam meningkatkan efektifitas dan efesien pelayanan dalam pengelolaan zakat.

4. Kompetensi dan peningkatan kapasitas Amil. Untuk menjalankan visi dan misi kebangkitan zakat, diperlukan sumber daya amil yang memiliki kompetensi dan kapasitas. Seiring dengan 
tuntutannya dan tantangan yang dihadapi saat ini, BAZNAS mendesain standar kompetensi amil serta program peningkatan kapasitas amil secara nasional.

5. Penguatan ekonomi kerakyatan. Memperjuangkan penegakkan ekonomi kerakyatan dan memberantas ketidakadilan ekonomi merupakan suatu hal yang penting.

6. Penguatan institusi keagamaan dan masyarakat. Tingkat partisipasi masyarakat melalui institusi keagamaan dan masyarakat di dalam memberdayakan mustahik di Indonesia sangat tinggi. Kontribusi ini diantaranya dalam bentuk sedekah formal dan informal. Untuk itu, BAZNAS memberikan apresiasi dan dukungan untuk meningkatkan kompetensi dan kapasitas institusinya di dalam memberdayakan mustahik.

7. Akseptabilitas BAZNAS di kalangan lembaga pemerintah. Kehadiran BAZNAS diharapkan mampu memperkuat hubungan antara BAZNAS Kabupaten Bengkalis dengan lembaga pemerintah sehingga meningkatkan kekuatan negosiasi dan akseptabilitas BAZNAS Kabupaten Bengkalis.

Berdasarkan hasil wawancara dengan BAZNAS Kabupaten Bengkalis maka sasaran implementasi strategi BAZNAS diantaranya Pengusaha, Dokter, Notaris, Pengusaha, Pegawai Negeri, Karyawan Swasta, Anggota DPRD, dan lain-lain. Berikut adalah prosedur pengumpulan dana zakat pada BAZNAS Kabupaten Bengkalis :

1. Membentuk Relawan BAZNAS untuk pengumpulan dan penyaluran.

2. Melakukan sosialisasi Zakat, Infak dan Sedekah.

3. Pengumpul Zakat menerima dan menjemput Zakat, Infak dan Sedekah di alamat muzakki.

4. Penghitungan zakat maal dilakukan oleh muzakki atau atas bantuan petugas BAZNAS.

5. Hasil pengumpulan zakat didayagunakan untuk mustahik sesuai dengan ketentuan agama.

Berdasarkan batasan masalah, berikut adalah data peningkatan muzakki di Kabupaten Bengkalis pada tahun 20172018:

Tabel 2. Jumlah Muzakki BAZNAS Kabupaten Bengkalis Tahun 2017-2018

\begin{tabular}{ccc}
\hline Tahun & Perorangan & UPZ \\
\hline 2017 & 160 & 28 \\
\hline 2018 & 1.320 & 32
\end{tabular}

Sumber : Dokumentasi BAZNAS Kabupaten Bengkalis(2020)

Berdasarkan data Tabel 2, dapat diketahui bahwa jumlah muzakki BAZNAS Kabupaten Bengkalis dari tahun 2017 ke tahun 2018 mengalami peningkatan yang signifikan. Pada tahun 2017 jumlah muzakki perorangan sebanyak 160 orang dan UPZ sebanyak 28, dan pada tahun 2018 Jumlah muzakki perorangan sebanyak 1320 orang dan UPZ sebanyak 32. Peningkatan ini dikarenakan pengelolaan dana zakat dilakukan secara melembaga sesuai dengan syariat Islam, amanah, kemanfaatan, keadilan, kepastian hukum, terintegrasi, dan akuntabilitas sehingga dapat meningkatkan efektivitas dan efesiensi pelayanan dalam pengelolaan zakat. Selain itu dengan adanya kemudahan muzakki dalam 
membayar zakat melalui setoran rekening. Seperti yang tertuang pada PERDA Zakat, Infak dan Sedekah Nomor 3 Tahun 2018 pada Pasal 21 yaitu : Muzakki dapat membayar zakatnya melalui nomor rekening BAZNAS Kabupaten atau LAZ.

Berdasarkan hasil penelitian dengan wawancara, maka dapat diambil kesimpulan bahwa peningkatan dana zakat pada BAZNAS Kabupaten Bengkalis dilakukan dengan strategi diantaranya adalah :

1. Peningkatan kerjasama dengan berbagai instansi termasuk instansi pemerintah;

2. Menambah frekuensi sosialisasi melalui pelaksanaan seminar dan workshop zakat;

3. Meningkatkan kompetensi SDM amil, UPZ dan relawan;

4. Mengembangkan sistem ICT dalam pengelolaan zakat

\section{Hambatan dalam Meningkatkan Pertumbuhan Dana Zakat pada Badan Amil Zakat Nasional Kabupaten Bengkalis}

Dari hasil penelitian yang telah penulis lakukan dapat diketahui hambatan Badan Amil Zakat Nasional Kabupaten Bengkalis dalam meningkatkan pertumbuhan Dana Zakat sebagai berikut :

1. Hambatan Internal

a. Kelemahan pada elemen customer relationship yaitu hubungan BAZNAS dengan muzakki baru, sebatas menghimpun dan menjemput. Belum sampai taraf mengambil zakat.

b. BAZNAS belum dapat memaksimalkan kerjasama dengan instansi dan lembaga pemerintah. Belum seluruh instansi dan lembaga pemerintah dapat dijangkau oleh BAZNAS.

c. Pemahaman tentang zakat yang belum merata di kalangan amil. Banyaknya amil yang bekerja di
BAZNAS dari latar belakang yang berbeda membuat pemahaman tentang zakat di kalangan amil beragam.

2. Hambatan Eksternal

a. Pemungutan zakat yang berlaku saat ini, memang belum sampai taraf mengambil zakat secara paksa dari muzakki. Hal ini karena regulasi belum mendukung penghimpunan zakat sampai kepada taraf tersebut.

b. Tingkat kepercayaan masyarakat terhadap BAZNAS relatif rendah. Sebagai lembaga pemerintah hal ini menyulitkan karena memberikan image yang kurang baik terhadap BAZNAS di mata umum.

c. Pemahaman tentang zakat yang masih rendah di kalangan masyarakat umum. Kurangnya informasi seputar zakat dan pengelolaan zakat di tengah masyarakat membuat tingkat pemahaman zakat masyarakat cenderung rendah dan beragam

\section{Analisis Strategi dalam Meningkatkan Pertumbuhan Dana Zakat pada Badan Amil Zakat Nasional Kabupaten Bengkalis}

Adapun analisis data yang dapat penulis jelaskan atau uraikan setelah membahas dari hasil rumusan masalah untuk penelitian yang telah dilakukan pada Badan Amil Zakat Nasional Kabupaten Bengkalis bisa kita melihat bahwa menurut Undang - Undang Nomor 23 Tahun 2011 Tentang Pengelolaan Zakat sebagaimana yang dimaksud pada Pasal 1 tentang Pengelolaan Zakat adalah kegiatan perencanaan, pelaksanaan, dan pengkoordinasian dalam pengumpulan, pendistribusian, dan pendayagunaan zakat. Dan pada Pasal 3 Pengelolaan Zakat bertujuan untuk meningkatkan efektivitas dan efesiensi pelayanan dalam pengelolaan zakat serta meningkatkan 
manfaat zakat untuk mewujudkan kesejahteraan masyarakat dan penanggulangan kemiskinan.

Tanpa implementasi yang baik dan mumpuni, perencanaan strategi tidak akan berhasil, visi, misi, nilai dan tujuan pun tidak akan tercapai. Meskipun strategi tersebut sudah disiapkan sebaik mungkin. Dalam pertumbuhan dana zakat, strategi digunakan agar tujuan dari pertumbuhan dana zakat dapat tercapai secara optimal.

Strategi yang digunakan dengan memaksimalkan penggunaan kekuatan internal dirumuskan dengan pertimbangan bahwa manajemen hendaknya memanfaatkan kekuatan lembaga dan keunggulan bersaing yang dimiliki untuk mengeksploitasi peluang yang tersedia. Manajemen BAZNAS meningkatkan kerja sama dengan pengurus masjid dan unit kerja Pemda. Dari data yang ada diketahui sampai saat ini sudah 28 UPZ yang bekerja sama dengan BAZNAS dalam menghimpun zakat.

Selain itu, strategi dengan menggunakan kekuatan internal untuk menghadapi dan meminimalisir ancamanancaman eksternal dilakukan untuk memanfaatkan peluang yang tersedia dengan mengeliminasi kelemahan lembaga. BAZNAS perlu menambah jumlah UPZ di lokasi-lokasi yang dinilai strategis. Lembaga atau instansi pemerintah, maupun di masjid-masjid.
Dengan jumlah masjid yang tidak sedikit di Kabupaten Bengkalis, tentu saja menjadi potensi luar biasa dalam menghimpun zakat. Inilah waktu yang tepat bagi BAZNAS Kabupaten Bengkalis berinteraksi dengan jamaah masjid.

Sosialisasi tentang zakat kepada masyarakat harus terus menerus digalakkan. Berbagai forum kajian seperti majlis taklim, pengajian, khutbah Jumat, seminar, perayaan hari raya, perayaan hari besar nasional, dan lain-lain, adalah media yang cukup efektif untuk mensosialisasikan zakat.

Strategi dengan mengatasi kelemahan internal dengan memanfaatkan kekuatan dan keunggulan yang dimiliki untuk menghindari efek negatif ancaman dari luar. Pihak BAZNAS sebagai koordinator pengelola zakat, maka perlu mendorong pemerintah untuk optimalisasi penghimpunan zakat. Hal tersebut dapat dilakukan dengan mendorong untuk dikeluarkannya berbagai perangkat aturan dan perundang-undangan yang dapat mendorong optimalisasi penghimpunan zakat. Sebagai contoh yang dapat diajukan adalah peraturan yang mengatur posisi zakat disamakan dengan pajak.

Berkaitan dengan pertumbuhan dana zakat setelah strategi diimplementasikan oleh BAZNAS Kabupaten Bengkalis, terdapat signifikansi yang cukup baik pada tiap tahunnya seperti tabel berikut: 
2020, Jurnal Tabarru' : Islamic Banking and Finance 3 (2) : 347 - 359

Tabel 3. Penerimaan Dana Zakat Tahun 2017

\begin{tabular}{|c|c|c|}
\hline Keterangan & \multicolumn{2}{|c|}{ Nominal (Rp) } \\
\hline Penerimaan Zakat Perorangan & $\mathrm{Rp}$ & 512.333 .250 \\
\hline Penerimaan Zakat Melalui Instansi (UPZ) & $\mathrm{Rp}$ & 288.044 .777 \\
\hline Penerimaan Ujrah Dana Zakat & $\mathrm{Rp}$ & 1.440 .981 \\
\hline Penerimaan Fidyah & & - \\
\hline Total Penerimaan Zakat & $\mathbf{R p}$ & 801.819.008 \\
\hline \multicolumn{3}{|c|}{ Sumber : Laporan Keuangan BAZNAS Kabupaten Bengkalis ( 2017) } \\
\hline \multicolumn{3}{|c|}{ Tabel 4. Penerimaan Dana Zakat Tahun 2018} \\
\hline Keterangan & \multicolumn{2}{|c|}{ Nominal (Rp) } \\
\hline Penerimaan Zakat Perorangan & $\mathrm{Rp}$ & 550.437 .898 \\
\hline Penerimaan Zakat Melalui Instansi (UPZ) & $\mathrm{Rp}$ & 846.647 .904 \\
\hline Penerimaan Bagi Hasil & $\mathrm{Rp}$ & 2.002 .198 \\
\hline Total Penerimaan Zakat & $\mathbf{R p}$ & 1.399.088.000 \\
\hline
\end{tabular}

Sumber : Laporan Keuangan BAZNAS Kabupaten Bengkalis (2018)

Dari Tabel 3. dan Tabel 4. dapat diketahui bahwa jumlah penerimaan dana zakat BAZNAS Kabupaten Bengkalis pada tahun 2017 dan tahun 2018 mengalami peningkatan signifikan. Pada tahun 2017 jumlah penerimaan dana zakat sebesar Rp. 801.819.008 dan pada tahun 2018 jumlah penerimaan dana zakat sebesar Rp 1.399.088.000.

Menurut pengamatan Amil BAZNAS Kabupaten Bengkalis yang disampaikan oleh Bagian Pengumpulan, ada 3 hal yang sangat mendasar yang menyebabkan peningkatan fundraising dana zakat khususnya di Bengkalis.

1. Pertama, semakin meningkatnya kesadaran berzakat bagi umat Islam.

2. Kedua, Pemerintah Daerah Kabupaten Bengkalis ikut memberikan dukungan dalam tujuan yang sama dengan mengesahkan PERDA Zakat, Infak dan Sedekah Nomor 3 Tahun 2018.
3. Ketiga, pemahaman masyarakat tentang zakat semakin baik dan masyarakat semakin mempercayai kepada BAZNAS Kabupaten Bengkalis dalam mengelola Zakat, Infak dan Sedekah.

\section{Solusi dalam Meningkatkan Pertumbuhan Dana Zakat pada Badan Amil Zakat Nasional Kabupaten Bengkalis}

Sebagai lembaga yang berada dibawah naungan Pemerintah Daerah, BAZNAS Kabupaten Bengkalis mendapat kepercayaan untuk mengelola $100 \%$ dana zakat untuk pendayagunaan yang dialokasikan kepada asnaf-asnaf. Meski demikian, perhatian Pemerintah Daerah kepada zakat masih sedikit. Posisi ini tidak begitu memberikan kekuatan untuk BAZNAS dalam pengumpulan zakat.

Kerjasama yang dilakukan dengan unit instansi kerja belum berjalan secara optimal. Masih banyaknya unit instansi 
pemerintah yang belum menerapkan wajib zakat. Selain BAZNAS, pemerintah memiliki peran penting yang mewakili BAZNAS untuk mendorong unit instansi kerja membayar zakat, pemerintah harus menegaskan regulasi yang lebih baik lagi agar masyarakat serta unit instansi kerja diwajibkan untuk membayar zakat.

Sebagai lembaga dengan sistem yang modern, BAZNAS Kabupaten Bengkalis sebagai pengelola harus dapat membangun komunikasi yang dialogis dengan masyarakat baik secara pemberi maupun sebagai penerima. Adapun solusi yang harus dilakukan BAZNAS dalam mengatasi hambatan-hambatannya meliputi :

1. Transparansi pengelolaan. Hal ini dibuktikan dengan publikasi pengelolaan kepada khalayak melalui media cetak, media online, dan keterlibatan komisi pengawas, akuntan publik, dan lain-lain.

2. Modernisasi pengelolaan, yang dirincikan dengan penerapan teknologi informasi berbasis komputer dan internet serta SOP yang baku.

3. Publikasi. Sebagai lembaga yang didirikan untuk publik, BAZNAS Kabupaten Bengkalis harus secara rutin mempublikasikan perkembangan pemikiran, program, dan informasi pengelolaan melalui akun media sosial dan website BAZNAS Kabupaten Bengkalis. Upaya ini dilakukan untuk memberikan informasi sekaligus penggalangan dana zakat. Mempublikasikan secara besarbesaran program pendayagunaan dan penyaluran dana zakat yang ada di BAZNAS Kabupaten Bengkalis adalah cara lain dalam pengelolaan zakat untuk meningkatkan kepercayaan muzakki. Dengan mempublikasikan para muzakki mengetahui bentuk konkrit dari dana yang telah mereka sumbangkan secara rutin digunakan untuk kegiatan apa saja dan disumbangkan kemana saja, sehingga meningkatkan kepercayaan kepada masyarakat lain untuk membayar zakat.

Selain itu upaya-upaya yang dilakukan BAZNAS Kabupaten Bengkalis dalam meningkatkan pertumbuhan dana zakat diantaranya adalah :

1. Melakukan penyuluhan dan pelatihan kepada UPZ, Muzakki, Desa/Kelurahan dan organisasi kemasyarakatan tentang kewajiban membayar zakat, apa-apa saja yang wajib dizakatkan, dan UndangUndang Nomor 23 Tahun 2011, Peraturan Daerah Zakat, Infak dan Sedekah Nomor 3 Tahun 2018.

2. Berusaha untuk mengelola zakat secara profesional serta mengusahakan tenaga-tenaga yang dapat bekerja fulltime.

3. Mengadakan pelaksanaan lokakarya dengan mengikut sertakan organisasi kemasyarakatan, para pengusahapengusaha tinggi, para muzakki dan pemerintah daerah.

4. Melakukan silaturrahim, ceramah, pelatihan, sarasehan, dan lain-lain.

5. Melakukan pengembangan SDM baik amil, muzakki maupun mustahik dengan diadakan pelatihan tentang Zakat.

Dari data tabel laporan keuangan diatas dapat diketahui bahwa peningkatan pada hasil pengumpulan dana zakat pada tahun 2018 meningkat dibanding tahun 2017. Hal ini menguatkan bahwa implementasi dari strategi yang sudah dilakukan oleh BAZNAS Kabupaten Bengkalis memiliki dampak yang positif pada hasil pengumpulan dana zakat. Namun dilihat dari sisi persentase peningkatan penghimpunan terjadi kecenderungan penurunan. Untuk itu, hambatan-hambatan yang dihadapi oleh BAZNAS Kabupaten Bengkalis perlu diatasi dengan sebaik mungkin, dengan 
SDM dan manajemen yang baik, strategistrategi yang matang serta dukungan dari pemerintah melalui regulasi-regulasi yang tepat, maka penghimpunan dana zakat akan meningkat secara optimal.

\section{KESIMPULAN}

Prosedur Pengumpulan yang
dilakukan oleh Badan Amil Zakat Nasional Kabupaten Bengkalis telah sesuai dengan yang telah ditetapkan, hal ini dibuktikan dengan meningkatnya dana zakat dengan sangat pesat pada tahun 2018. Strategi yang digunakan antara lain peningkatan kerjasama dengan berbagai instansi termasuk instansi pemerintah; menambah frekuensi sosialisasi melalui pelaksanaan seminar dan workshop zakat; meningkatkan kompetensi SDM amil, UPZ dan relawan; mengembangkan sistem ICT dalam pengelolaan zakat. Hambatan yang dihadapi Badan Amil Zakat Nasional Kabupaten Bengkalis yang paling tampak adalah kurangnya pemahaman masyarakat tentang zakat dan kurangnya kepercayaan masyarakat kepada Badan Amil Zakat Nasional Kabupaten Bengkalis akan tetapi hambatan tersebut masih dapat dihadapi dengan dilaksanakannya secara rutin kegiatan sosialisasi dan lainnya sehingga pengumpulan dana zakat mengalami peningkatan. Adapun solusi yang diterapkan oleh BAZNAS Kabupaten Bengkalis untuk mengatasi hambatan diantaranya adalah transparansi pengelolaan; modernisasi pengelolaan dan publikasi. Adapun saran-saran yang dapat penulis sampaikan sebagai solusi untuk Badan Amil Zakat Nasional Kabupaten Bengkalis diantaranya adalah mempertahankan dan menerapkan strategi dan fungsi manajemen yang lebih baik lagi agar tetap dapat mempertahankan peningkatan dalam pengumpulan dana zakat pada tahun-tahun berikutnya; kepada pemerintah sebaiknya lebih menekankan kepada instansi-instansi yang ada di Kabupaten Bengkalis melalui
PERDA zakat, infak dan sedekah Nomor 3 Tahun 2018 untuk membayar zakat; perguruan tinggi sebaiknya menerapkan metode pembelajaran mengenai zakat lebih dalam lagi, dan agar bisa dilakukan sosialisasi mengenai zakat di kampuskampus.

\section{DAFTAR PUSTAKA}

Ali, Nuruddin. 2006. Zakat sebagai Instrumen dalam Kebijakan Fiskal. PT Raja Grafindo. Jakarta.

Fajri, Ahmad. 2020. Strategi Pengumpulan Zakat Badan Amil Zakat Nasional Kota Padang. Jurnal At-Taghyir, 2(2), 233-247.

Hafidhuddin, Didin. 2002. Zakat dalam Perekonomian Modern. Gema Insani. Jakarat.

Hasan, Ali. 2006. Zakat dan Infak. Kencana Prenada Media Group. Jakarta.

Kadir dan Nafis. 2017. Strategi Pengumpulan Dana Zakat Pada Badan Amil Zakat Infaq dan Shadaqah (BAZIS) Provinsi DKI Jakarta. Jurnal Middle East And Islamic Studies, 4(1), 107-123.

Khasanah, Umrotul. 2010. Manajemen Zakat Modern : Instrumen Pemberdayaan Ekonomi Umat. UIN Maliki Press. Malang.

Mannan, M. Abdul. 1997. Teori dan Praktek Ekonomi Islam. PT. Dana Bhakti Prima Yasa. Yogyakarta.

Mufraini, Arief. 2006. Akuntansi dan Manajemen Zakat. GP Press. Jakarta.

Tjiptono, Fandy. 2008. Strategi Pemasaran. CV. Andi Offset. Yogyakarta.

Trianto. 2015. Riset Modelling. Adh Dhuha Institute. Pekanbaru.

Yusuf, Muri. 2014. Metode Penelitian, Edisi Pertama. Kencana. Jakarta. 